although we were living in times of financial stress, when it was impossible to devote as much money as could be wished to work of this character, he was not without hope that the outcome of Sir Leonard's visit would be greatly to the advantage of the cause of Indian archæological exploration and research. His concluding remarks were especially noteworthy : "As a people", he said, "we should surely stand condemned if, when judgment was passed on us at the bar of history, it should be said of us that we had neglected in our long contact with India those cultural values, which alone raised man above the level of the animal world and were an index of his achievement in the domain of the spirit."

\section{Neanderthal Man in Central Asia}

AN announcement of a discovery in the Uzbek republic of the U.S.S.R. of very considerable interest is announced by the Russia To-day Press Service. The skeleton and other traces of man of palæolithic age have been found in a cave some twelve miles north-west of the town of Baisun. Stone implements found on the site are said to fix the date of the stratum, in which the discovery was made, as late Mousterian. Prof. Gerasimov, the well-known Russian archæologist, has succeeded in restoring the skull, and a commission has been appointed, which will make a special study of the reconstructed relic. These remains are the first indisputable signs of palæolithic man to be found in central Asia, and previously no traces of the Mousterian culture had been known to occur there. The skull, it is stated, was found lying under a single stratum, close to the wall of the cave, while the remainder of the skeleton lay scattered beside it. The remains are those of a child of about eight years of age; and as it is in a fair state of preservation, it is possible to decide that it differs markedly in structure from the human skeleton of to-day. The contour of the skull, particularly, is said to recall that of the anthropoid ape-a statement which, at first sight, seems to conflict with the further comment that it is said to refute the racial theory that present-day man developed independently of Neanderthal man. The trend of recent discovery, it may be pointed out, would certainly not necessarily be widely at variance with modernistic tendencies in a skull of such a facies, but until further details are to hand judgment one way or the other is obviously premature.

\section{Introduction of Screw Propulsion}

Ar a meeting of the Newcomen Society held at the Science Museum on April 19, in a paper entitled "The First Twenty Years of Screw Propulsion 1838-58", Engineer Captain E. C. Smith gave some interesting information regarding the early inventors of screw propellers, Sir Francis Pettit Smith, John Ericsson, George Lowe, George Blaxland and Bennet Woodcroft, whose names were most closely associated in the minds of their contemporaries with the early trials of sea-going screw-driven vessels and the adoption of the screw-propeller on a wide scale. It was appropriate, Capt. Smith said, that the subject should be dealt with at a meeting at the Science Museum, for Bennet Woodcroft was the virtual founder of that institution, while Smith was for some fourteen years the curator under Woodcroft. Both these pioneers were buried in Brompton Cemetery, and their tombstones mention their participation in the introduction of the screw. Ericsson's work began with his patent of July 1836, the building of the little Francis B. Ogden and then the slightly larger Robert F. Stockton. Soon after the trials of the latter in the Thames in 1839, she was sailed to America; Ericsson soon followed her and it was in the United States that his main work in connexion with screw propulsion was done, his most notable vessel being the U.S.S. Princeton, built in 1841-43. She was the first screw-driven warship ever launched. By 1850 , about a hundred and fifty American vessels had been fitted with the screw. The most important work in England was done by Smith, but of this Capt. Smith is to deal with in a future paper. In an appendix to the paper prepared by Dr. H. W. Dickinson, Mr. A. A. Gomme and Mr. E. W. White, a review was given of the various law cases which arose out of the patents and over which a vast amount of time, energy and money were wasted.

\section{Acquisitions at the British Museum (Natural History)}

ThE trustees of the Museum have purchased for the Department of Geology the terminal section of a tail-sheath of an extinct giant armadillo (Hoplophorus sp.) discovered in the Pleistocene deposits of Santa Fé, Argentine. The giant armadillos had a solid bony shell and armour of the same type on the head and tail. When danger threatened, they withdrew their limbs into the shell, closed the head end by means of the bony casque, and lashed the club-like tail from side to side so as to ward off attack from the rear. Some genera had massive horny spikes on the end of the tail, but in Hoplophorus the tail was covered with scales. The Department of Mineralogy has acquired a superb specimen of chessylite from Tsumeb in South-West Africa, and an extremely beautiful specimen with bright yellow plates of wulfenite (lead molybdate) on a glistening white ground of calcite crystals from Arizona. The Department has also purchased from the widow of the late Dr. A. E. H. Tutton a collection of the salts, chiefly double sulphates and selenates of the alkalis (potassium, rubidium, cæsium, etc.), utilized by Dr. Tutton in his researches on the relation between physical properties and chemical composition in isomorphous series of compounds. An important addition to the departmental library is a first edition of the "Speculum Lapidum" by Camillus Leonardus, physician to Cæsar Borgia, to whom the book is dedicated. It is a fine example of the printing press of Sessa in Venice. The book was one of the most widely read 'lapidaries' of the time, and its editions ran from the first in Latin in 1502 (forty-four years before Agricola's "De Natura Fossilium") to an English edition in 1750 , bridging the gap between medieval and modern mineralogy. The late Frederick Adams of Jersey has bequeathed to the Department 